OPEN ACCESS

Edited by:

Suvendu Das,

Gyeongsang National University,

South Korea

Reviewed by:

Kristof Brenzinger,

Netherlands Institute of Ecology

(NIOO-KNAW), Netherlands

Ye Deng,

Research Center

for Eco-Environmental Sciences

(CAS), China

${ }^{*}$ Correspondence:

Santosh Ranjan Mohanty

mohantywisc@gmail.com; santosh.mohanty@icar.gov.in

Specialty section: This article was submitted to

Terrestrial Microbiology, a section of the journal

Frontiers in Microbiology

Received: 15 September 2018 Accepted: 26 March 2019

Published: 14 May 2019

Citation:

Mohanty SR, Nagarjuna M, Parmar R, Ahirwar U, Patra A

Dubey G and Kollah B (2019) Nitrification Rates Are Affected by Biogenic Nitrate and Volatile Organic

Compounds in Agricultural Soils.

Front. Microbiol. 10:772

doi: 10.3389/fmicb.2019.00772

\section{Nitrification Rates Are Affected by Biogenic Nitrate and Volatile Organic Compounds in Agricultural Soils}

\author{
Santosh Ranjan Mohanty*, Mounish Nagarjuna, Rakesh Parmar, Usha Ahirwar, \\ Ashok Patra, Garima Dubey and Bharati Kollah \\ ICAR Indian Institute of Soil Science, Bhopal, India
}

The processes regulating nitrification in soils are not entirely understood. Here we provide evidence that nitrification rates in soil may be affected by complexed nitrate molecules and microbial volatile organic compounds (mVOCs) produced during nitrification. Experiments were carried out to elucidate the overall nature of mVOCs and biogenic nitrates produced by nitrifiers, and their effects on nitrification and redox metabolism. Soils were incubated at three levels of biogenic nitrate. Soils containing biogenic nitrate were compared with soils containing inorganic fertilizer nitrate $\left(\mathrm{KNO}_{3}\right)$ in terms of redox metabolism potential. Repeated $\mathrm{NH}_{4}-\mathrm{N}$ addition increased nitrification rates $\left(\mathrm{mM} \mathrm{NO}_{3}{ }^{1-}\right.$ produced $\mathrm{g}^{-1}$ soil $\left.\mathrm{d}^{-1}\right)$ from 0.49 to 0.65 . Soils with higher nitrification rates stimulated $(p<0.01$ ) abundances of $16 \mathrm{~S}$ rRNA genes by about eight times, amoA genes of nitrifying bacteria by about 25 times, and amoA genes of nitrifying archaea by about 15 times. Soils with biogenic nitrate and $\mathrm{KNO}_{3}$ were incubated under anoxic conditions to undergo anaerobic respiration. The maximum rates of different redox

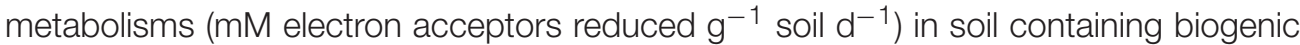
nitrate followed as: $\mathrm{NO}_{3}{ }^{1-}$ reduction $4.01 \pm 0.22, \mathrm{Fe}^{3+}$ reduction $5.37 \pm 0.12, \mathrm{SO}_{4}{ }^{2-}$ reduction $9.56 \pm 0.16$, and $\mathrm{CH}_{4}$ production $\left(\mu \mathrm{g} \mathrm{g}^{-1}\right.$ soil) $0.46 \pm 0.05$. Biogenic nitrate inhibited denitrificaton 1.4 times more strongly compared to mineral $\mathrm{KNO}_{3}$. Raman spectra indicated that aliphatic hydrocarbons increased in soil during nitrification, and these compounds probably bind to $\mathrm{NO}_{3}$ to form biogenic nitrate. The mVOCs produced by nitrifiers enhanced $(p<0.05)$ nitrification rates and abundances of nitrifying bacteria. Experiments suggest that biogenic nitrate and mVOCs affect nitrification and redox metabolism in soil.

Keywords: nitrification, biogenic nitrate, redox metabolism, mVOCs, 16S rRNA, amoA

\section{INTRODUCTION}

Nitrification is a key biogeochemical process for the global nitrogen cycle (Nelson et al., 2016). Therefore, in-depth knowledge on nitrification is essential for agricultural, environmental, and economic reasons. Nitrification of ammonia to nitrate is a two-step process usually performed by two distinct groups of chemolitho-autotrophic microbes (Alfreider et al., 2017), one step oxidizes $\mathrm{NH}_{4}{ }^{+}$to $\mathrm{NO}_{2}{ }^{1-}$, while the other oxidizes $\mathrm{NO}_{2}{ }^{1-}$ to $\mathrm{NO}_{3}{ }^{1-}$ (Li Y. et al., 2018). In the first step, most of the $\mathrm{NH}_{4}{ }^{+}$is converted to $\mathrm{NO}_{2}{ }^{1-}$, but a small portion of the $\mathrm{N}$ is emitted as $\mathrm{N}_{2} \mathrm{O}$ (Liimatainen et al., 2018). This is produced as a byproduct when the intermediate $\mathrm{HNO}$ is produced during the oxidation of $\mathrm{NH}_{2} \mathrm{OH}$ to $\mathrm{NO}_{2}{ }^{1-}$. $\mathrm{HNO}$ is further oxidized to $\mathrm{NO}_{2}{ }^{1-}$ and finally to 
$\mathrm{NO}_{3}{ }^{1-}$ (Weber et al., 2015). Complete ammonia oxidation (comammox) is energetically feasible and bacteria (Nitrospira sp.) capable of performing both steps have been identified (Daims et al., 2015). These bacteria encode all enzymes necessary for ammonia oxidation via nitrite to nitrate in their genomes (van Kessel et al., 2015).

Most ammonia oxidizing bacteria (AOB) belong to the Betaproteobacteria ( $\beta$-AOB) (Pan et al., 2018). There are two distinct phylogenetic clusters within the $\beta$-AOB, the Nitrosomonas cluster and the Nitrosospira cluster (Zhao et al., 2015). The Nitrosomonas cluster comprises members of the genus Nitrosomonas. The Nitrosospira cluster comprises the genera Nitrosospira, Nitrosolobus, and Nitrosovibrio. Nitrite $\left(\mathrm{NO}_{2}{ }^{1-}\right)$ oxidizing bacteria have been described in four genera; Nitrobacter, Nitrococcus, Nitrospina, and Nitrospira (Han et al., 2017). Our understanding of the nitrogen cycle has been revised in the past few years by the discovery of ammonia oxidizing archaea (AOA) (Leininger et al., 2006). AOA are members of the proposed archaeal phylum Thaumarchaea (Gribaldo et al., 2010). However, AOA are difficult to cultivate, so some aspects of their physiology and contribution to biogeochemical pathways are still speculative. AOA are found in almost all environments. Crenarchaeotal 16S rRNA gene sequences have been recovered from different environments including Pacific and Atlantic oceans (Flood et al., 2015), lake sediments (Lliros et al., 2014), the guts of animals (Radax et al., 2012), agricultural soils (Tourna et al., 2011), and forest soils (Isobe et al., 2012). Typically AOA greatly outnumber AOB. In soil samples, the copy number of crenarchaeotal $a m o A$ is one to three orders of magnitude higher than bacterial amoA (Wuchter et al., 2006).

Nitrification is carried out by the microbial membrane-bound enzymes. The ammonia monooxygenase (AMO) is responsible for the conversion of $\mathrm{NH}_{3}$ to hydroxylamine (Bock and Wagner, 2013). The end product of nitrification, $\mathrm{NO}_{3}{ }^{1-}$, may binds to cationic molecules present in soil or extracellular microbial molecules. Thus, the $\mathrm{NO}_{3}{ }^{1-}$ produced by nitrifiers can be different in nature than inorganic $\mathrm{NO}_{3}{ }^{1-}$. The nitrates produced from nitrification may bind to extracellular complex organic compounds to form "biogenic nitrate." Contrastingly, inorganic forms of $\mathrm{NO}_{3}\left(\mathrm{NaNO}_{3}, \mathrm{KNO}_{3}, \mathrm{NH}_{4} \mathrm{NO}_{3}\right.$, etc.) are in the form of salts. The bonding between $\mathrm{NO}_{3}{ }^{1-}$ and cations $(\mathrm{Na}$, $\mathrm{K}, \mathrm{NH}_{4}$, etc) in inorganic $\mathrm{NO}_{3}$ fertilizer is stronger than the bonding between $\mathrm{NO}_{3}{ }^{1-}$ and cellular organic cations in biogenic nitrate. Therefore, nitrate in the inorganic nitrate fertilizer preferably does not bind to cellular organic cations unlike the nitrate produced through nitrification. It is also reported that nitrifiers produce soluble microbial products (SMPs) which serve as supplementary organic substrates for heterotrophic bacteria (Dolinšek et al., 2013). The SMPs are mainly constituted of proteins and humics (Li J. et al., 2018). There is a possibility that after nitrification the product $\left(\mathrm{NO}_{3}{ }^{1-}\right)$ binds to SMPs forming "biogenic nitrate." Like inorganic nitrate, the biogenic nitrate has two main biological functions. Either it is assimilated by plants and microbes (under aerobic condition) (Rubio-Asensio et al., 2014) or it is denitrified when anoxic conditions prevail. Nitrate reduction or denitrification is carried out by dissimilatory nitrate reducing bacteria (Castro-Barros et al., 2017). However, due to its complexation with SMPs, the availability and fate of biogenic nitrate can be different from inorganic fertilizer nitrate $\left(\mathrm{KNO}_{3}\right)$.

Like other microorganisms, nitrifiers can produce volatile organic compounds (VOCs). However, information on the VOCs emitted by nitrifiers is scarce. Microbial VOCs (mVOCs) act as signal molecules for different microorganisms (Insam and Seewald, 2010). The mVOCs can modulate activities of the producing species, or of different microbial species. However, it is unclear how the volatiles produced by nitrifiers influence the activity of nitrifiers and denitrifiers. The manuscript aims to define how the $\mathrm{NO}_{3}{ }^{1-}$ derived from nitrification is different from that in chemical inorganic nitrate fertilizers.

\section{MATERIALS AND METHODS}

\section{Soil Sampling and Characterization}

Experiments were carried out using soil samples collected during September 2016 from the experimental fields of the Indian Institute of Soil Science, Bhopal, Madhya Pradesh, India (23.30 $\mathrm{N}, 77.40 \mathrm{E}, 485 \mathrm{~m}$ above mean sea level). The soil is a heavy clayey Vertisol (typic Haplustert, WRB code VR), characterized by: $5.7 \mathrm{~g}$ $\mathrm{kg}^{-1}$ organic C, $225 \mathrm{mg} \mathrm{kg}^{-1}$ available $\mathrm{N}, 2.6 \mathrm{mg} \mathrm{kg}^{-1}$ available $\mathrm{P}$, and $230 \mathrm{mg} \mathrm{kg}^{-1}$ available $\mathrm{K}$. The textural composition of soil was: sand $15.2 \%$, silt $30.3 \%$, clay $54.5 \%$, electrical conductivity (EC) $0.43 \mathrm{dS} \mathrm{m}^{-1}$, and $\mathrm{pH} 7.5$. The soil had $863.24 \mu \mathrm{M} \mathrm{NO}_{3}{ }^{1-}$, $0.01 \mu \mathrm{M} \mathrm{Fe}^{2+}$, and $101.02 \mu \mathrm{M} \mathrm{SO}_{4}{ }^{2-}$. Concentration of these ions was estimated by wet chemical method as given below (chemical analysis). After collection, the soil was hand-processed after breaking the clods and removing roots and stones. Soil was then passed through 2-mm mesh sieve and was used within 2 days of collection.

\section{Nitrification and Biosynthesis of Biogenic Nitrate}

Biogenic nitrate is defined here as the nitrate produced via nitrification. To biosynthesize biogenic nitrate, microcosms were prepared where nitrification was carried out three times (Figure 1). The choice of having three repeated $\mathrm{NH}_{4}$ additions was based on the fact that in agriculture, $\mathrm{N}$ fertilizer is often applied in split doses, and for most crops, three split doses of $\mathrm{N}$ are recommended (Arregui and Quemada, 2008). Repeated nitrification resulted in different levels of nitrate (biogenic nitrate). Experiments were carried out in six 1000-ml bottles (Figure 1). Three bottles served as controls (AC1-AC3) and the other three were used for biosynthesis of biogenic nitrate and estimation of nitrification (labeled as BC1-BC3). To each bottle $200 \mathrm{~g}$ soil was added and sterilized double distilled water was added to maintain soil at $60 \%$ moisture holding capacity (MHC). There was no ammonium amendment to "AC" bottles, while $2 \mathrm{ml}$ of $1 \mathrm{M} \mathrm{NH}_{4}-\mathrm{N}\left(\mathrm{NH}_{4} \mathrm{Cl}\right)$ was added the "BC" bottles, giving a final concentration of $10 \mathrm{mM}$. Soils were mixed thoroughly using a glass rod and bottles were closed with butyl rubber caps. All the bottles were incubated at $30 \pm 2{ }^{\circ} \mathrm{C}$. At different times, bottles $\mathrm{BC} 1-\mathrm{BC} 3$ were opened and 1-g soil subsamples were taken out to determine $\mathrm{NO}_{3}{ }^{1-}$ concentrations. Control bottles 

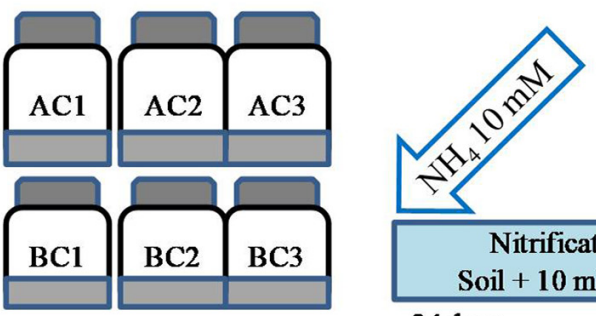

Nitrification I Soil $+10 \mathrm{mM} \mathrm{NH}_{4}$ 24 days (24 days
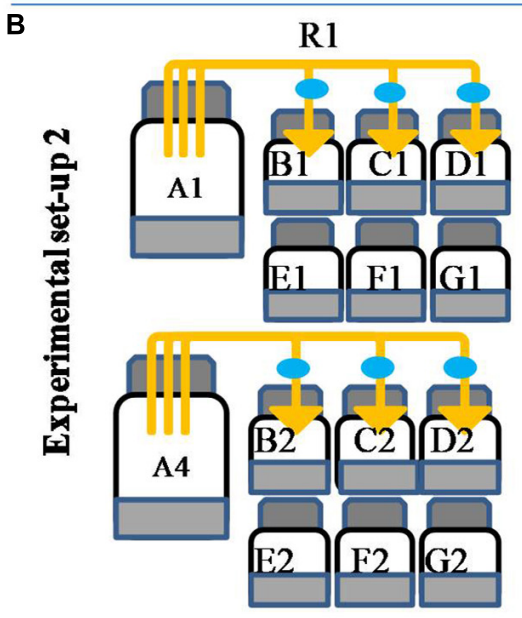

$\mathrm{R} 2$

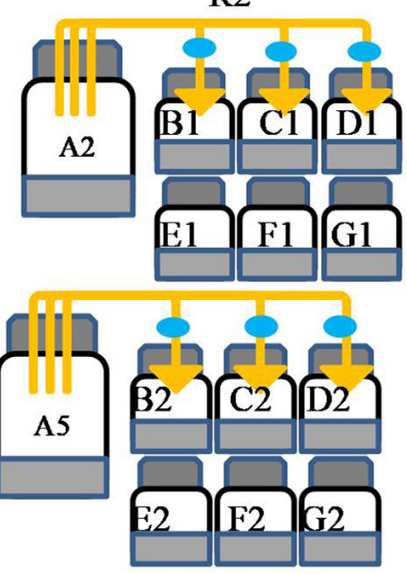

R3

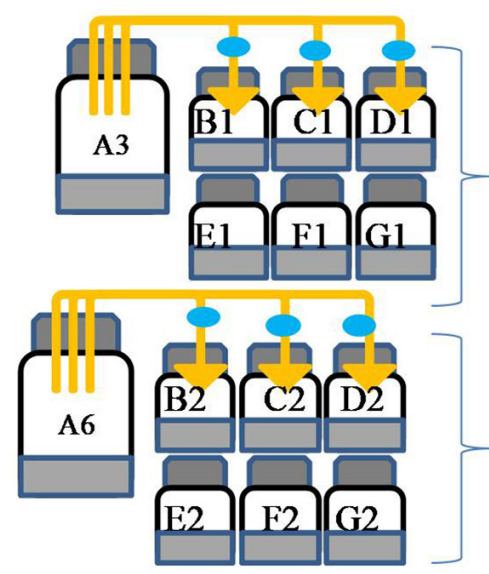

Nitrification III Soil + $30 \mathrm{mM} \mathrm{NH}_{4}$ 55 days

FIGURE 1 | Microcosm design for biosynthesis of biogenic nitrate and estimation of nitrification potential of soil under repeated $\mathrm{NH}_{4}-\mathrm{N}$ amendment (setup 1 , A). Microcosm setup to evaluate the effect of microbial volatiles (mVOCs) on nitrification and denitrification (setup 2, B). Bottles of $250 \mathrm{ml}$ volume contained $50 \mathrm{~g}$ soil and were un-amended (AC1-AC3) or amended with $10 \mathrm{mM} \mathrm{NH}_{4}$ (BC1-BC3). After complete nitrification of $10 \mathrm{mM} \mathrm{NH}_{4}$ (24 days) a second dose of $\mathrm{NH}_{4}$ was added (BC bottles) and after complete nitrification (40 days) a third dose of $10 \mathrm{mM} \mathrm{NH}_{4}$ was added (BC bottles). The third nitrification stage was completed in 55 days of incubation. The three complete nitrification phases were designated as nitrification I, nitrification II, and nitrification III. The second setup (B) was designed to evaluate the effect of mVOCs (A1-A6) on nitrification and denitrification. All experimental treatments included three replicates (R1, R2, R3). The six source bottles (A1-A6) were connected to 18 sink bottles (130 ml volume containing $20 \mathrm{~g}$ of soil), shown as B1, C1, D1, B2, C2, and D2. The control bottles (130 ml bottle containing $20 \mathrm{~g}$ soil) were without exposure to mVOCs (E1, F1, G1 and E2, F2, G2). The connectors fitted with $0.2-\mu \mathrm{m}$ filters (filled circle) were used to connect source and sink bottles. After each nitrification stage, one sink bottle and one control bottle were further incubated to determine nitrification and denitrification rates as mentioned the methodology.

were also opened for analysis to mimic the treated ones. Nitrate measurement continued till the $\mathrm{NO}_{3}{ }^{1-}$ concentrations in $\mathrm{BC}$ bottles reached a plateau. Nitrification of the first dose of $\mathrm{NH}_{4}-$ $\mathrm{N}(10 \mathrm{mM})$ was referred as "nitrification I." After nitrification I, $10 \mathrm{mM}$ of $\mathrm{NH}_{4}-\mathrm{N}$ was again added to $\mathrm{BC}$ bottles and the same incubation and measurement protocol applied until the $\mathrm{NO}_{3}{ }^{1-}$ was again stabilized. This second nitrification stage was referred as "nitrification II." Subsequently, the bottles were again opened and amended with a third dose of $10 \mathrm{mM} \mathrm{NH}_{4}-\mathrm{N}$ in BC bottles. The third nitrification stage was referred as "nitrification III." The three nitrification stages (nitrification I, II, and III) produced three levels of biogenic nitrate. After completion of each nitrification stage, 20-g soil was taken from the bottles ( $\mathrm{AC}$ and $\mathrm{BC}$ ) and incubated to evaluate redox metabolism as described below.

\section{The Effect of Biogenic Nitrate on Redox Metabolism}

To evaluate the effect of biogenic nitrate on redox metabolism, experiments were carried out as described above (AC1-AC3 and
BC1-BC3). In addition, 18 130-ml vials were also used for this analysis. Nine vials were kept for evaluating redox metabolism using soil mixed with equivalent amount of inorganic fertilizer nitrate $\left(\mathrm{KNO}_{3}\right)$ as observed in nitrification vials (labeled as $\mathrm{A}$ ). Another nine vials were used for evaluating redox metabolism using the soil in which biogenic nitrate was produced (labeled as B). Each set of nine vials was represented as three nitrification phases and three replicates. Soil $(20 \mathrm{~g})$ from $\mathrm{AC} 1-\mathrm{AC} 3$ and BC1-BC3 bottles (collected after nitrification I, II, and III) were placed into $130-\mathrm{ml}$ serum vials. Soils were mixed with $10 \mathrm{mM}$ of $\mathrm{CH}_{3} \mathrm{COONa}$, and $50 \mathrm{ml}$ of sterile distilled water. Acetate served as carbon source for anaerobic microbial metabolism. After mixing the contents, bottles were closed with rubber septa and sealed using aluminum crimp seals. Bottles were incubated at $30 \pm 2^{\circ} \mathrm{C}$ with shaking at 100 revolutions per minute (rpm) on an orbital shaker for 30 days. To determine the temporal variation in the reduction of the terminal electron acceptors, $3 \mathrm{ml}$ of slurry from each vial was withdrawn using a syringe (Dispovan, India). Before sampling, the syringes were first flushed with pure $\mathrm{N}_{2}$ to maintain anoxic conditions. Slurry samples 
were processed following standard methods to estimate $\mathrm{NO}_{3}{ }^{1-}$, $\mathrm{Fe}^{3+}, \mathrm{SO}_{4}{ }^{2-}$ (see below). Changes in the concentrations of all electron acceptors $\left(\mathrm{NO}_{3}{ }^{1-}, \mathrm{Fe}^{3+}, \mathrm{SO}_{4}{ }^{2-}\right)$ were measured at each sampling time to estimate the rates of redox metabolism. Headspace gas samples of the vials were analyzed via gas chromatography (see below) to quantify $\mathrm{CH}_{4}$ production at the end of the incubation period (30 days).

\section{Effects of $\mathrm{N}_{2} \mathrm{O}$ and Microbial Volatiles on Nitrification}

To test the effect of $\mathrm{N}_{2} \mathrm{O}$ on nitrification, experiments were carried out by placing $20 \mathrm{~g}$ soil into six $130-\mathrm{ml}$ sterilized serum bottles. Soils were moistened with sterilized double distilled water to maintain $60 \% \mathrm{MHC}$ and $\mathrm{NH}_{4}-\mathrm{N}$ was added to a final concentration of $10 \mathrm{mM}$. After mixing the contents, bottles were closed with rubber septa and sealed with aluminum crimp seals. Three bottles were kept as controls and three were injected with pure $\mathrm{N}_{2} \mathrm{O}$ (Inox Pvt. Ltd., Bhopal, India) to a final mixing ratio of 10 ppmv. Control vials were injected with pure helium (99\%) instead of $\mathrm{N}_{2} \mathrm{O}$. All bottles were incubated at $30 \pm 2{ }^{\circ} \mathrm{C}$ for 30 days. At different incubation, periods bottles were opened and $1 \mathrm{~g}$ amounts of soil taken to measure $\mathrm{NO}_{3}{ }^{1-}$. After each $\mathrm{NO}_{3}{ }^{1-}$ measurement, bottles were re-incubated with 10 ppmv $\mathrm{N}_{2} \mathrm{O}$.

To evaluate the effect of mVOCs on nitrification and denitrification, an experiment was set up as shown in Figure 1; $50 \mathrm{~g}$ amounts of soil were placed into 250 - $\mathrm{ml}$ bottles, and sterile double distilled water added to maintain soil at $60 \%$ MHC. To each bottle, $10 \mathrm{mM} \mathrm{NH}_{4}-\mathrm{N}$ was added. Bottles were closed with rubber stoppers and tightened with screw caps. Three bottles were controls and six "source bottles" were the source of mVOCs originating from nitrification. Another set of 36 "sink bottles" were $130 \mathrm{ml}$ serum bottles each containing $20 \mathrm{~g}$ of soil at $60 \%$ MHC. The headspace of one source bottle was connected with three sink bottles using silicon tubes $(45 \mathrm{~cm}$ long $\times 0.5 \mathrm{~cm}$ internal diameter), each fitted with a needle $(1.20 \mathrm{~mm} \times 38 \mathrm{~mm})$ at one end and a $0.2 \mu \mathrm{m}$ syringe filter $(25 \mathrm{~mm})$ and needle $(1.20 \mathrm{~mm} \times 38 \mathrm{~mm})$ at the other end. The syringe filters were used to restrict any microbial cross contamination between source bottles and sink bottles. The needles of both ends of the silicon tubes were pierced into the rubber caps of source and sink bottles. Gas phases of source and sink bottles were mixed via repeated (10 times) flushing (withdrawing and injecting) of the headspace of the sink bottles using a $50 \mathrm{ml}$ syringe. A total of 18 sink bottles were connected with six source bottles, and another 18 sink bottles were not connected and served as "mVOCs control." All bottles were kept in an incubator maintained at $30 \pm 2{ }^{\circ} \mathrm{C}$ in the dark. Headspace gas samples of all sink bottles were analyzed for $\mathrm{N}_{2} \mathrm{O}$. Nitrification was measured only in the bottles labeled as "controls."

Nitrification of $10 \mathrm{mM} \mathrm{NH}_{4}-\mathrm{N}$ in the source bottles was repeated three times as described earlier. The three nitrification stages were referred to as nitrification I, nitrification II, and nitrification III. At the completion of each nitrification phase, three sink bottles and three control bottles were removed and used for evaluating nitrification and denitrification rates. To measure nitrification in these bottles, $10 \mathrm{mM} \mathrm{NH}_{4}-\mathrm{N}$ was added and the accumulation of $\mathrm{NO}_{3}{ }^{1-}$ was determined. Denitrification was measured by adding $10 \mathrm{mM} \mathrm{NO}_{3}{ }^{-}\left(\mathrm{KNO}_{3}\right)$ and $50 \mathrm{ml}$ of sterile distilled water. Decline in $\mathrm{NO}_{3}{ }^{1-}$ concentrations was measured to determine denitrification.

\section{Chemical Analyses}

Soil nitrate content was estimated after extraction with $\mathrm{CaSO}_{4}$ and reaction by the phenol disulfonic acid method (Jackson, 1958). Reduced $\mathrm{Fe}^{2+}$ was determined by extracting slurries with $0.5 \mathrm{~N} \mathrm{HCl}$ and ferrozine assay (Stookey, 1970). Sulfate $\left(\mathrm{SO}_{4}{ }^{2-}\right)$ content was estimated by extracting slurries with $\mathrm{Ca}\left(\mathrm{H}_{2} \mathrm{PO}_{4}\right)_{2}$ and turbidometric analysis (Searle, 1979). The slopes of regression lines relating the changes in $\mathrm{NO}_{3}-\mathrm{N}$ concentrations with the incubation time were used to determine the potential rates of nitrification or denitritrification (nitrification: $\mu \mathrm{g} \mathrm{NO}_{3}{ }^{1-}$ produced $\mathrm{g}^{-1}$ soil $\mathrm{d}^{-1}$; denitrification: $\mu \mathrm{g} \mathrm{NO}{ }^{1-}$ consumed $\mathrm{g}^{-1}$ soil $\mathrm{d}^{-1}$ ) (Schmidt and Belser, 1982). Potential iron $\left(\mathrm{Fe}^{3+}\right)$ reduction rates were estimated from the increase of $\mathrm{Fe}^{2+}$ in slurries over time, and potential sulfate reduction rates were determined from declining $\mathrm{SO}_{4}{ }^{2-}$ concentrations.

Gas samples of $0.1 \mathrm{ml}$ were withdrawn from the headspaces of the vials using a gas-tight syringe. After each sampling, the headspace was replaced with an equivalent amount of high purity (>99\%) helium ( $\mathrm{He}$ ) to maintain atmospheric pressure. Gas analysis was carried out using a gas chromatograph (GC 2010, CIC, India) fitted with flame ionization detector (FID) and electron capture detector (ECD). Gas samples were introduced through the port of an on-column injector. The GC was calibrated before and after each set of measurements using different mixtures of gasses $\left(\mathrm{CO}_{2}\right.$ or $\mathrm{CH}_{4}$ or $\mathrm{N}_{2} \mathrm{O}$ ) in $\mathrm{N}_{2}$ (Inox Gas, Bhopal, India) as primary standards. Primary standards were $\mathrm{CO}_{2}$ (500, 1000 ppmv), $\mathrm{CH}_{4}$ (10 and $100 \mathrm{ppmv}$ ), and $\mathrm{N}_{2} \mathrm{O}$ (1 and 10 ppmv).

To quantify $\mathrm{CO}_{2}$ and $\mathrm{CH}_{4}$, a Porapak Q column (2 m length, internal diameter $3.175 \mathrm{~mm}, 80 / 100$ mesh, stainless steel column) was used in combination with the FID. The $\mathrm{CO}_{2}$ was quantified after its conversion to $\mathrm{CH}_{4}$ using a attached methanizer module at $350^{\circ} \mathrm{C}$. The injector, column, and detector (FID) were maintained at 120,60 , and $330^{\circ} \mathrm{C}$, respectively. $\mathrm{N}_{2} \mathrm{O}$ was estimated using a stainless steel column ( $2 \mathrm{ft}$; diameter, $1 / 8 \mathrm{in})$ filled with chromosorb 101 (60-80 mesh) coupled to the ECD. The oven temp was $30^{\circ} \mathrm{C}$, the injector and detector (ECD) temp were 120 and $330^{\circ} \mathrm{C}$, respectively.

\section{Raman Spectroscopic Analysis of Soil}

To test the hypothesis that $\mathrm{NO}_{3}{ }^{1-}$ derived through nitrification is a complex mixture of $\mathrm{NO}_{3}{ }^{1-}$ and cellular derived biomolecules, and to reveal any compositional changes of soil due to nitrification, soil samples were analyzed by Raman spectrophotometry (Guizani et al., 2017). Soil samples of unnitrified control and after third nitrification (nitrification III) were dried at room temperature. The dried soil samples were ground using a mortar and pestle and passed through a $0.1-\mathrm{mm}$ sieve. Samples were scanned in a high-resolution Raman spectrometer (RamanStation ${ }^{\mathrm{TM}}$ 400F, Perkin-Elmer ${ }^{\circledR}$, Beaconsfield, Buckingham-shire, United Kingdom) fitted with 
Czerny-Turner type achromatic spectrograph. The spectral resolution was $0.4 \mathrm{~cm}^{-1}$ pixel $^{-1}$ at the spectral range of 200$1050 \mathrm{~nm}$ and the source of excitation was a $632.8 \mathrm{~nm}$, air cooled $\mathrm{He}-\mathrm{Ne}$ laser. Nomenclature of wavelengths and the representing functional groups was based on the earlier publications (Socrates, 2004; Colthup, 2012). Data obtained from the instrument were normalized. Wavelengths representing each functional group were considered for analysis. Intensities of the peaks were added and the average of three replicates was calculated.

\section{DNA Extraction}

DNA was extracted from $0.5 \mathrm{~g}$ field soil samples using the ultraclean DNA extraction kit (MoBio, United States) according to the manufacturer's instructions. The DNA concentrations were determined in a biophotometer (Eppendorf, Germany) by measuring absorbance at $260 \mathrm{~nm}$ (A260), assuming that 1 A260 unit corresponds to $50 \mathrm{ng}$ of DNA per $\mu \mathrm{l}$. DNA extraction was further confirmed by electrophoresis on a $1 \%$ agarose gel. The extracted DNA was dissolved in $50 \mu \mathrm{l}$ TE buffer and stored at $-20^{\circ} \mathrm{C}$ until further analysis.

\section{Real-Time PCR Quantification of Total Bacteria, Ammonia Oxidizing Bacteria, and Ammonia Oxidizing Archaea}

Microbial abundance was estimated from two experimental setups: first with soil samples of un-incubated control, nitrification I, II, and III soils, and second with soil samples exposed to microbial volatiles (mVOCs) of nitrification III and un-exposed controls. The microbial groups estimated were total bacteria, AOB, and AOA. Real-time PCR was performed on a Step one plus real-time PCR (ABI, United States). Reaction mixtures contained $2 \mu \mathrm{l}$ of DNA template, $10 \mu \mathrm{l}$ of $2 \mathrm{X}$ SYBR green master mix (Affymetrix, United States), and $200 \mathrm{nM}$ of each primer (GCC Biotech, New Delhi). The final volume of PCR reaction mixture was made to $20 \mu \mathrm{l}$ with PCR grade water (MP Bio, United States). Primers targeting bacterial 16S rRNA genes, bacterial $a m o A$ genes, and archaeal $a m o A$ gene were used to quantify the respective microbial abundance. The primers (5'-3') for bacteria were 1F (CCT ACG GGA GGC AGC AG) and 518R (ATT ACC GCG GCT GCT GG) (Baek et al., 2010); nitrifying bacteria 1F (GGG GTT TCT ACT GGT GGT) and amoA 2R1 (CCC CTC TGG AAA GCC TTC TTC) (Okano et al., 2004); nitrifying archaea arc-Amo-F (STA ATG GTC TGG CTT AGA CG; $\mathrm{S}=\mathrm{G}$ or $\mathrm{C}$ ); and arc-amoa-R (GCG GCC ATC CAT CTG TAT GT) (Mutlu and Guven, 2011). Thermal cycling was carried out by an initial denaturizing step at $94^{\circ} \mathrm{C}$ for $4 \mathrm{~min}, 40$ cycles of $94^{\circ} \mathrm{C}$ for $1 \mathrm{~min}$, the assay-dependent annealing temperature for $30 \mathrm{~s}, 72^{\circ} \mathrm{C}$ for $45 \mathrm{~s}$; and a final extension at $72^{\circ} \mathrm{C}$ for $5 \mathrm{~min}$. The annealing temperature for $16 \mathrm{~S}$ rRNA genes was $52^{\circ} \mathrm{C}$, and for $a m o A$ genes of bacteria and archaea were 50 and $52^{\circ} \mathrm{C}$, respectively. Fluorescence was measured during the elongation step. Data analysis was carried out with Step one plus software (ABI, United States) as described in user's manual. The cycle at which the fluorescence of target molecule number exceeded the background fluorescence (threshold cycle $\left[C_{T}\right]$ ) was determined from dilution series of target amplicons with defined target molecule amounts. $C_{T}$ was proportional to the logarithm of the target molecule number. The quality of PCR amplification products was determined by melting curve analysis with temperature increase of $0.3^{\circ} \mathrm{C}$ per cycle. Standard for bacteria prepared by using Escherichia coli strain JM 109 (Promega Inc., United States). For preparing standard for amoA genes of nitrifying bacteria and nitrifying archaea, the PCR products of bacterial amoA and archaeal amoA genes were separately cloned to TOPO TA cloning vector (Invitrogen, United States). Constructed plasmids were transformed into competent cells (One Shot Top 10, Invitrogen, United States). Transformed cells (white colonies) were multiplied in LB broth for $24 \mathrm{~h}$ at $37^{\circ} \mathrm{C}$ and their concentration was estimated using a Biophotometer (Eppendorf, Germany). Plasmids from the E. coli or transformed cells were extracted using a plasmid extraction kit (Axygen, United States). Concentration of plasmids was quantified and expressed as ng $\mu \mathrm{L}^{-1}$. Serial dilution for each plasmid was prepared and real-time PCR carried out. Standard curve for each gene was prepared by plotting plasmid concentration (representing cell number or gene copies) versus $\mathrm{C}_{T}$ values (Supplementary Table S1).

\section{Statistical Analysis}

All statistical analyses were carried out using the "agricolae" packages of the statistical software $\mathrm{R}$ (2.15.1) (Ihaka and Gentleman, 1996). Data obtained were presented as arithmetic mean of three replicated observations. Effect of factors $\left(\mathrm{NH}_{4}\right.$ amendment) on the parameters (nitrification, denitrification, $\mathrm{Fe}^{3+}$ reduction, $\mathrm{SO}_{4}{ }^{2-}$ reduction, $\mathrm{CH}_{4}$ production, and microbial abundance) was tested by analysis of variance (ANOVA). Low $P$-value and high F statistics indicated significant impact of the factors on the variables. To define the significant difference among the treatments, Tukeys honestly significant difference (HSD) test was performed.

\section{RESULTS}

\section{Nitrification Activity of Soil}

Variation of $\mathrm{NO}_{3}{ }^{1-}$ concentrations during repeated stages of nitrification is shown in Figure 2. Nitrification increased steadily after 5 days of incubation. Nitrification of the first dose of $10 \mathrm{mM} \mathrm{NH}_{4}-\mathrm{N}$ occurred within 24 days. Subsequent amendment of $\mathrm{NH}_{4}-\mathrm{N}$ stimulated nitrification. The second dose of $10 \mathrm{mM} \mathrm{NH}_{4}-\mathrm{N}$ was nitrified by 40 days while the third dose of $10 \mathrm{mM} \mathrm{NH}_{4}-\mathrm{N}$ was nitrified by 55 days. The added $\mathrm{NH}_{4}-\mathrm{N}$ was nitrified by about $84 \%$ in nitrification I, $92 \%$ in nitrification II, and $87 \%$ in nitrification III stages. Potential nitrification rates (PNRs) increased with repeated nitrification (Table 1). PNR of fresh soil was $0.49 \mathrm{mMg}^{-1}$ soil $\mathrm{d}^{-1}$ while the PNR of nitrification III soil was highest of $0.65 \mathrm{mMg}^{-1}$ soil d $\mathrm{d}^{-1}$.

\section{Effect of Nitrification on Microbial Abundance}

Abundances of total bacteria, nitrifying bacteria, and nitrifying archaea all increased after repeated nitrification (Table 1). The 


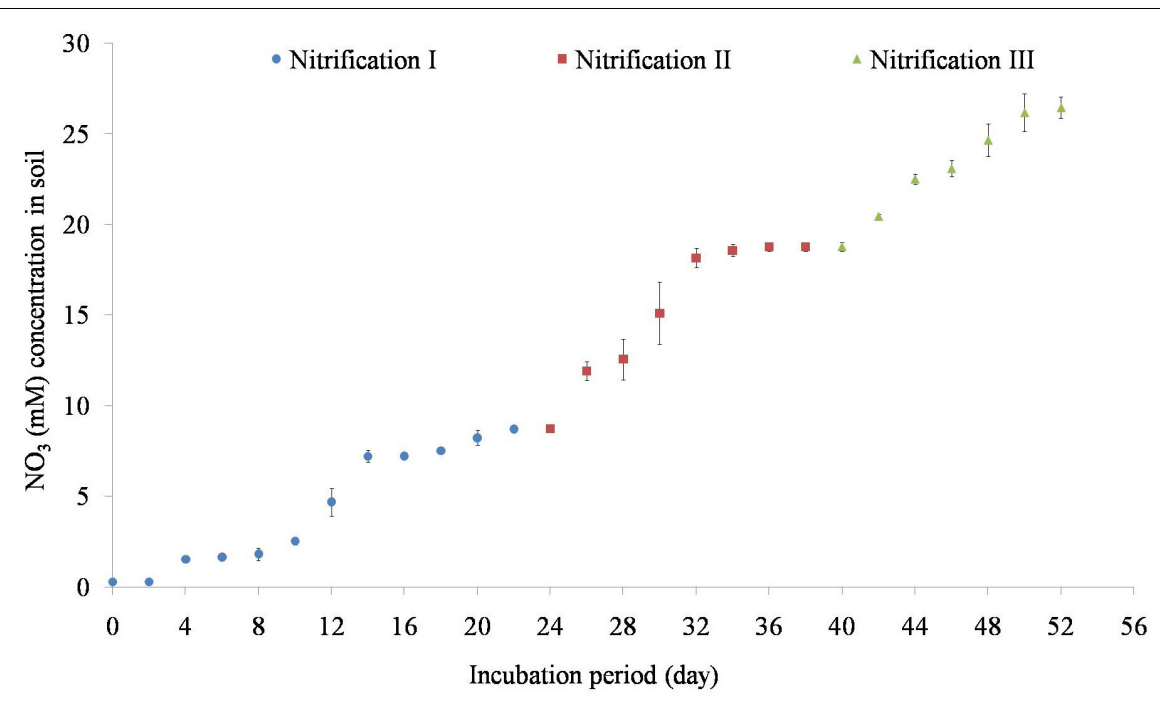

FIGURE 2 | Temporal variation of nitrification in response to $10 \mathrm{mM} \mathrm{NH}_{4}-\mathrm{N}$ amendment. Nitrification was estimated as the increase in $\mathrm{NO}_{3}{ }^{1-}$ concentration after $\mathrm{NH}_{4}-\mathrm{N}$ amendment. After complete nitrification, soils were again amended with $10 \mathrm{mM} \mathrm{NH}_{4}$ for a second and a third time to complete three nitrification stages (nitrification I, nitrification II, and nitrification III). Each data point represents an arithmetic mean with standard deviation of three replicates.

TABLE 1 | Nitrification and microbial abundance in soil after nitrification of three successive $10 \mathrm{mM} \mathrm{NH}_{4}-\mathrm{N}^{2}$ amendments.

\begin{tabular}{|c|c|c|c|c|}
\hline Nitrification & $\begin{array}{l}\text { Nitrification rate }\left(\mathrm{mM} \mathrm{NO}{ }_{3}^{1-}\right. \\
\left.\text { produced } \mathrm{g}^{-1} \text { soil d }^{-1}\right)\end{array}$ & $\begin{array}{c}\text { Bacteria ( } \times 10^{6} 16 \mathrm{~S} \text { rRNA } \\
\text { gene copies } \mathrm{g}^{-1} \text { soil) }\end{array}$ & $\begin{array}{l}\text { Nitrifying bacteria ( } \times 10^{4} \text { bacterial } \\
\text { amoA gene copies } \mathrm{g}^{-1} \text { soil) }\end{array}$ & $\begin{array}{c}\text { Nitrifying archaea ( } \times 10^{4} \text { archaeal } \\
\text { amoA gene copies } \mathrm{g}^{-1} \text { soil) }\end{array}$ \\
\hline Unincubated control & & $5.00 \pm 1.00$ & $4.00 \pm 1.46$ & $6.00 \pm 1.00$ \\
\hline Nitrification I & $0.49 \pm 0.01$ & $16.67 \pm 5.69$ & $32.33 \pm 6.43$ & $58.00 \pm 8.19$ \\
\hline Nitrification II & $0.56 \pm 0.09$ & $29.00 \pm 7.81$ & $66.00 \pm 11.53$ & $71.00 \pm 16.52$ \\
\hline Nitrification III & $0.65 \pm 034$ & $43.67 \pm 4.51$ & $102.33 \pm 8.50$ & $94.33 \pm 7.77$ \\
\hline
\end{tabular}

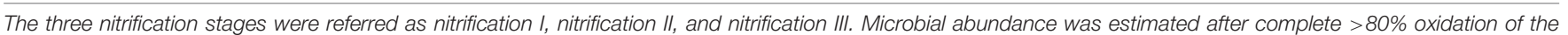
added ammonium. Soil without added ammonium served as a control. Values represent arithmetic means and standard deviation of three replicates.

bacterial population varied from 5 to $43.67\left(\times 10^{6}\right.$ cells $\mathrm{g}^{-1}$ soil). The nitrifying bacterial population ranged from 4 to 102 $\left(\times 10^{4}\right.$ cells $\mathrm{g}^{-1}$ soil) and the nitrifying archaeal population varied from 6 to $94.33\left(\times 10^{4}\right.$ cells $\mathrm{g}^{-1}$ soil $)$. The lowest abundances were measured in control treatments and the highest in the nitrification III soil samples.

\section{Effect of Nitrification on Redox Metabolism}

Redox metabolism followed the classical trend of sequential reduction of terminal electron acceptors (Figure 3), starting with $\mathrm{NO}_{3}{ }^{1-}$ reduction followed by $\mathrm{Fe}^{3+}$ reduction, $\mathrm{SO}_{4}{ }^{2-}$ reduction, and $\mathrm{CH}_{4}$ production. Soil amended with inorganic $\mathrm{KNO}_{3}$ exhibited detectable nitrate reduction after 2 days and complete denitrification within 5 days. Iron reduction peaked at 5 days and $\mathrm{SO}_{4}{ }^{2-}$ reduction after 2 weeks. Potential redox metabolic rates are presented in Table 2. Denitrification rates increased with $\mathrm{NO}_{3}{ }^{1-}$ concentration originating from either nitrification phases or $\mathrm{KNO}_{3}$. However, the denitrification rate was lower in the soil that had undergone nitrification than compared to the $\mathrm{KNO}_{3}$ treated soil. Denitrification may have been inhibited by biogenic nitrate. The reduction rate of $\mathrm{Fe}^{3+}$ was also lower in the nitrification soil. Similarly, the reduction of $\mathrm{SO}_{4}{ }^{2-}$ was also low in the nitrification soil. Production of $\mathrm{CH}_{4}$ was estimated after the end of incubation. $\mathrm{CH}_{4}$ production was low in nitrification soil compared to non-nitrification soil (Table 2).

\section{Statistical Analyses}

Analysis of variance indicated that $\mathrm{NH}_{4}-\mathrm{N}$ addition significantly and positively influenced nitrification $(p<0.0001)$ (Table 3 ). It also significantly influenced $\mathrm{NO}_{3}{ }^{1-}$ reduction $(p<0.0001)$, and $\mathrm{Fe}^{3+}$ reduction $(p<0.01)$ compared to or inorganic nitrate amendment. However, $\mathrm{SO}_{4}{ }^{2-}$ reduction and $\mathrm{CH}_{4}$ production were not significantly affected. Abundances of $16 \mathrm{~S}$ rRNA genes, amo $A$ genes of nitrifying bacteria, and $a m o A$ genes of nitrifying archaea were significantly $(p<0.0001)$ influenced by the $\mathrm{NH}_{4}$ amendment.

\section{Raman Spectra of Soil in Response to Nitrification}

Soil samples were scanned by a Raman spectrometer to examine how soil organic carbon changed due to the metabolism of nitrifiers (Figure 4). Nitrified soil (nitrification III) had high absorbance for the wavelengths (wavenumbers $\mathrm{cm}^{-1}$ ) between 500-1000 and 1500-2000. Absorbance intensity was 


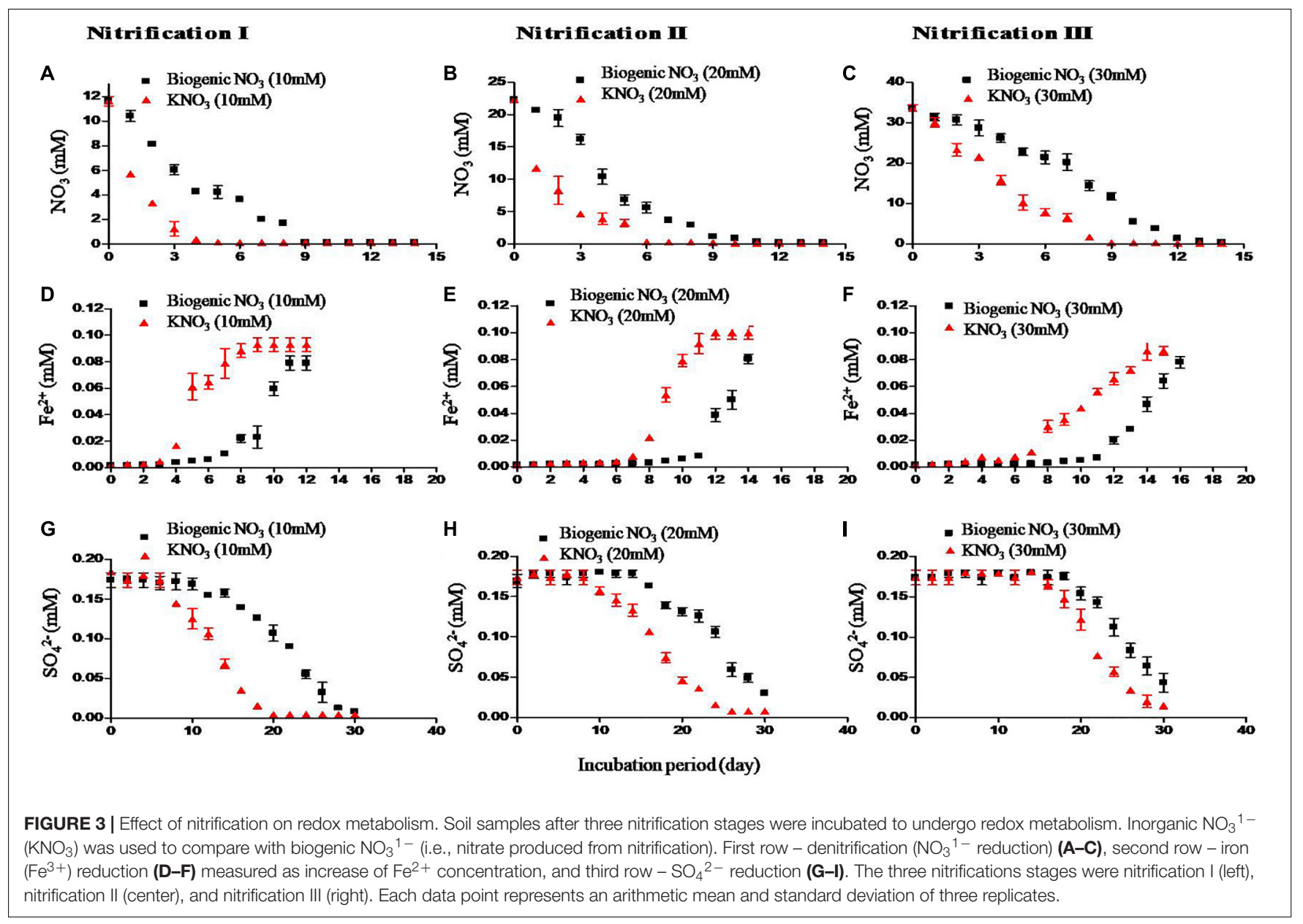

low for the wavelengths ranging from 1200-1600. Raman intensity for the above wavelengths was plotted for both the samples (Figure 4). Nitrification increased the concentration of $\mathrm{C}-\mathrm{C}, \mathrm{C}-\mathrm{S}, \mathrm{C}-\mathrm{O}-\mathrm{C}$ molecules and decreased $\mathrm{C}-\mathrm{NO}_{2}$, and $\mathrm{CH}_{2}$ molecules.

\section{Production of $\mathrm{N}_{2} \mathrm{O}$ and $\mathrm{CO}_{2}$ From Soil During Nitrification}

Headspace $\mathrm{N}_{2} \mathrm{O}$ and $\mathrm{CO}_{2}$ production were measured from control soil (no added nitrogen) and soil after the three nitrification stages (Table 4). $\mathrm{N}_{2} \mathrm{O}$ production rates varied from 4.06 to $19.39 \mu \mathrm{g} \mathrm{g}^{-1}$ soil $\mathrm{d}^{-1}$. The lowest rate was in control soil and the highest was in nitrification III soil. The amount of headspace $\mathrm{CO}_{2}$ varied from $465 \mathrm{\mu g} \mathrm{g}^{-1}$ soil $\mathrm{d}^{-1}$ in control soil to $649 \mu \mathrm{g} \mathrm{g}^{-1}$ soil $\mathrm{d}^{-1}$ in nitrification III soil. The values of $\mathrm{N}_{2} \mathrm{O}$ varied significantly among the treatments.

\section{Effect of $\mathrm{N}_{2} \mathrm{O}$ and Nitrifying Microbial Volatiles on Nitrification and Denitrification}

The effect of $\mathrm{N}_{2} \mathrm{O}$ on the nitrification and denitrification was evaluated by exposing soil to 0 or $10 \mathrm{ppm}$ of $\mathrm{N}_{2} \mathrm{O}$. Production of $\mathrm{NO}_{3}{ }^{1-}$ was measured during nitrification, while the decline of $\mathrm{NO}_{3}{ }^{1-}$ was measured during denitrification. Nitrification of $10 \mathrm{mM} \mathrm{NH}_{4}$ was completed in 3 weeks whereas the denitrificaion of $\mathrm{NO}_{3}{ }^{1-}(\sim 10 \mathrm{mM})$ was completed within 8 days. Added $\mathrm{N}_{2} \mathrm{O}$ had no significant effect on nitrification and denitrification (Figure 5).

The effect of volatiles originating from nitrification was tested on nitrification and denitrification (Figure 5). The composition of nitrifier-derived mVOCs was not evaluated in this study because the primary aim was to reveal the influence of mVOCs on nitrification and denitrification. Soils were exposed to microbial volatiles of three repeated nitrification (nitrification I, II, and III) phases. The mVOCs originating from nitrifiers significantly stimulated nitrification (Figure 5). Time required for complete nitrification of the added $\mathrm{NH}_{4}$ was significantly reduced due to the volatiles. Nitrification rates $\left(\mathrm{mM} \mathrm{NO}_{3}{ }^{1-}\right.$ produced $\mathrm{g}^{-1}$ soil $\mathrm{d}^{-1}$ ) varied from 0.425 in control soil to 0.844 in nitrification III soil. Nitrification and denitrification values of the controls remained unchanged over the three nitrification phases. However, mVOCs of nitrifiers did not influence denitrification. Potential denitrification rates $\left(\mathrm{mM} \mathrm{NO}_{3}{ }^{1-}\right.$ reduced $\mathrm{g}^{-1}$ soil d $\left.{ }^{-1}\right)$ varied from 1.37 to 1.38 with no statistical difference among the treatments (Table 4). 
TABLE 2 | Influence of biogenic $\mathrm{NO}_{3}{ }^{1-}$ and inorganic fertilizer $\mathrm{KNO}_{3}$ on soil denitrification rate, iron reduction rate, sulfate reduction rate, and methane production rate.

\begin{tabular}{|c|c|c|c|c|c|}
\hline $\begin{array}{l}\text { Source of } \\
\mathrm{NO}_{3}{ }^{1-}\end{array}$ & $\begin{array}{l}\text { Nitrification } \\
\text { phases }\end{array}$ & $\begin{array}{c}\text { Denitrification rate }(\mathrm{mM} \\
\left.\mathrm{NO}_{3}{ }^{1-} \text { reduced } \mathrm{g}^{-1} \text { soil } \mathrm{d}^{-1}\right)\end{array}$ & $\begin{array}{l}\text { Iron reduction rate }\left(\mu \mathrm{M} \mathrm{Fe}^{3+}\right. \\
\left.\text { reduced } \mathrm{g}^{-1} \text { soil } \mathrm{d}^{-1}\right)\end{array}$ & $\begin{array}{l}\text { Sulfate reduction rate }(\mu \mathrm{M} \\
\left.\mathrm{SO}_{4}{ }^{2-} \text { reduced } \mathrm{g}^{-1} \text { soil } \mathrm{d}^{-1}\right)\end{array}$ & $\begin{array}{c}\mathrm{CH}_{4} \text { production ( } \mu \mathrm{g} \mathrm{CH}_{4} \\
\text { produced } \mathrm{g}^{-1} \text { soil) }\end{array}$ \\
\hline \multirow[t]{2}{*}{ Biogenic $\mathrm{NO}_{3}{ }^{1-}$} & Nitrification I & $1.22 \pm 0.04$ & $5.29 \pm 0.26$ & $9.41 \pm 0.14$ & $0.54 \pm 0.04$ \\
\hline & Nitrification III & $2.80 \pm 0.04$ & $2.89 \pm 0.10$ & $9.19 \pm 0.06$ & $0.38 \pm 0.04$ \\
\hline $\begin{array}{l}\text { Inorganic fertilizer } \\
\mathrm{NO}_{3}{ }^{1-}\end{array}$ & Nitrification I & $1.63 \pm 0.17$ & $8.55 \pm 0.58$ & $10.89 \pm 0.17$ & $0.63 \pm 0.11$ \\
\hline$\left(\mathrm{KNO}_{3}\right)$ & Nitrification III & $4.01 \pm 0.22$ & $5.37 \pm 0.12$ & $9.56 \pm 0.16$ & $0.46 \pm 0.05$ \\
\hline
\end{tabular}

The three nitrification stages were referred as nitrification I, nitrification II, and nitrification III. Soil sub-samples collected at the end of the three nitrification phases were incubated for redox metabolism. Values represent arithmetic means and standard deviations of three replicates.

\section{Microbial Abundance in Response to Microbial Volatiles}

The effect of nitrifying mVOCs on the soil microbial abundance was estimated by quantifying the $16 \mathrm{~S}$ rRNA genes of eubacteria, $a m o A$ genes of nitrifying bacteria, and $a m o A$ genes of nitrifying archaea. Exposure of soils to mVOCs of nitrification (nitrification III) did not increased microbial abundance in soils (Table 5). This indicated that the mVOCs were not a substantial substrate for growth of soil microorganisms. However, prior exposure of soils to mVOCs and subsequent incubation for nitrification resulted in a significant increase in the growth of nitrifying bacteria. Probably, the mVOCs may have activated the nitrifiers in some way resulting high microbial abundance.

\section{Raman Spectra of Soil Exposed to Nitrifying Microbial Volatiles}

Soils after exposure to the nitrification III and control (unexposed) treatments were analyzed by Raman spectra (Figure 5). The Raman intensity across the total wavelengths of the two samples was mostly equivalent with no apparent change.

\section{DISCUSSION}

$\mathrm{NO}_{3}{ }^{1-}$ influences (mostly negatively) reduction of $\mathrm{Fe}^{3+}$ (Ionescu et al., 2015), $\mathrm{SO}_{4}{ }^{2-}$ (Ontiveros-Valencia et al.,

TABLE 3 | Analysis of variance (ANOVA) to determine the effect of $\mathrm{NH}_{4}$ amendment on nitrification, denitrification, sulfate reduction, $\mathrm{CH}_{4}$ production, abundance of bacterial $16 S$ rRNA genes, amoA of nitrifying bacteria, and $a m o A$ of nitrifying archaea.

\begin{tabular}{lcc}
\hline Parameters & F statistics & $P$-value \\
\hline Nitrification & 80.37 & $<0.0001$ \\
$\mathrm{NO}_{3}{ }^{1-}$ reduction & 2997 & $<0.0001$ \\
$\mathrm{Fe}^{3+}$ reduction & 21 & $<0.01$ \\
$\mathrm{SO}_{4}{ }^{2-}$ reduction & 1.349 & 0.285 \\
$\mathrm{CH}_{4}$ production & 3.955 & 0.187 \\
$16 \mathrm{~S}$ rRNA genes of eubacteria & 52.73 & $<0.0001$ \\
amoA genes of nitrifying bacteria & 103.5 & $<0.0001$ \\
amoA genes of nitrifying archaea & 16.21 & $<0.01$
\end{tabular}

2013), and methanogenesis (Rissanen et al., 2017). Denitrification is thermodynamically more favorable than the reduction of other electron acceptors $\left(\mathrm{Fe}^{3+}\right.$, $\left.\mathrm{SO}_{4}{ }^{2-}, \mathrm{CO}_{2}\right)$. This influence of inorganic nitrate on redox metabolism is well understood. However, the role of biogenic $\mathrm{NO}_{3}{ }^{1-}$ on redox metabolism is not known. Therefore, the interaction between nitrification (which produces biogenic nitrate) and redox metabolism was explored.

Soils were amended with $10 \mathrm{mM} \mathrm{NH} \mathrm{NH}_{4}-\mathrm{N}$ and the progress of nitrification was monitored. The PNRs measured were similar to those observed in other soils (Fierer et al., 2001). The nitrification was repeated three times to generate three levels of $\mathrm{NO}_{3}{ }^{1-}$ (biogenic nitrate). Nitrification rates increased over repeated $\mathrm{NH}_{4-}$ $\mathrm{N}$ amendments, as did the abundance of both nitrifying bacteria and archaea. After each nitrification stage, the soils were evaluated for redox metabolism. Soil samples were incubated under flooded moisture regime to test the effect of the biogenic nitrate versus inorganic nitrate (control) on redox metabolism. Biogenic nitrate inhibited reduction of electron acceptors compared to inorganic $\mathrm{NO}_{3}{ }^{1-}$. This is reasonable as any compound or processes that inhibited denitrification will ultimately affect the reduction of subsequent terminal electron acceptors $\left(\mathrm{Fe}^{3+}\right.$, $\mathrm{SO}_{4}{ }^{2-}, \mathrm{CO}_{2}$ ).

The production of biogenic nitrate via nitrification significantly $(p<0.05)$ inhibited redox metabolism compared to the addition of inorganic $\mathrm{NO}_{3}{ }^{1-}$. Several soil factors may have been affected by the nitrification phase. One possibility is that nitrifiers produced biomolecules which inhibited the redox metabolism. To identify those biomolecules, soils of non-nitrified control soil and soil from the nitrification III stage were analyzed by Raman spectrometer. Soils of nitrification III were selected for Raman spectra analysis because these soils had undergone maximum nitrification. Raman spectra differentiated soil of control (with an equivalent amount of $\mathrm{KNO}_{3}$ ) from soils of nitrification III. Nitrification increased the abundance of functional groups including C-C, C-S, C-O-C. Spectra also indicated that nitrification decreased the amount of functional groups including $\mathrm{C}-\mathrm{NO}_{2}$, $\mathrm{CH}_{2} / \mathrm{CH}_{3}, \mathrm{C}-\mathrm{NO}_{2}, \mathrm{C}-\mathrm{N}$, esters, and alkynes. Therefore, the 


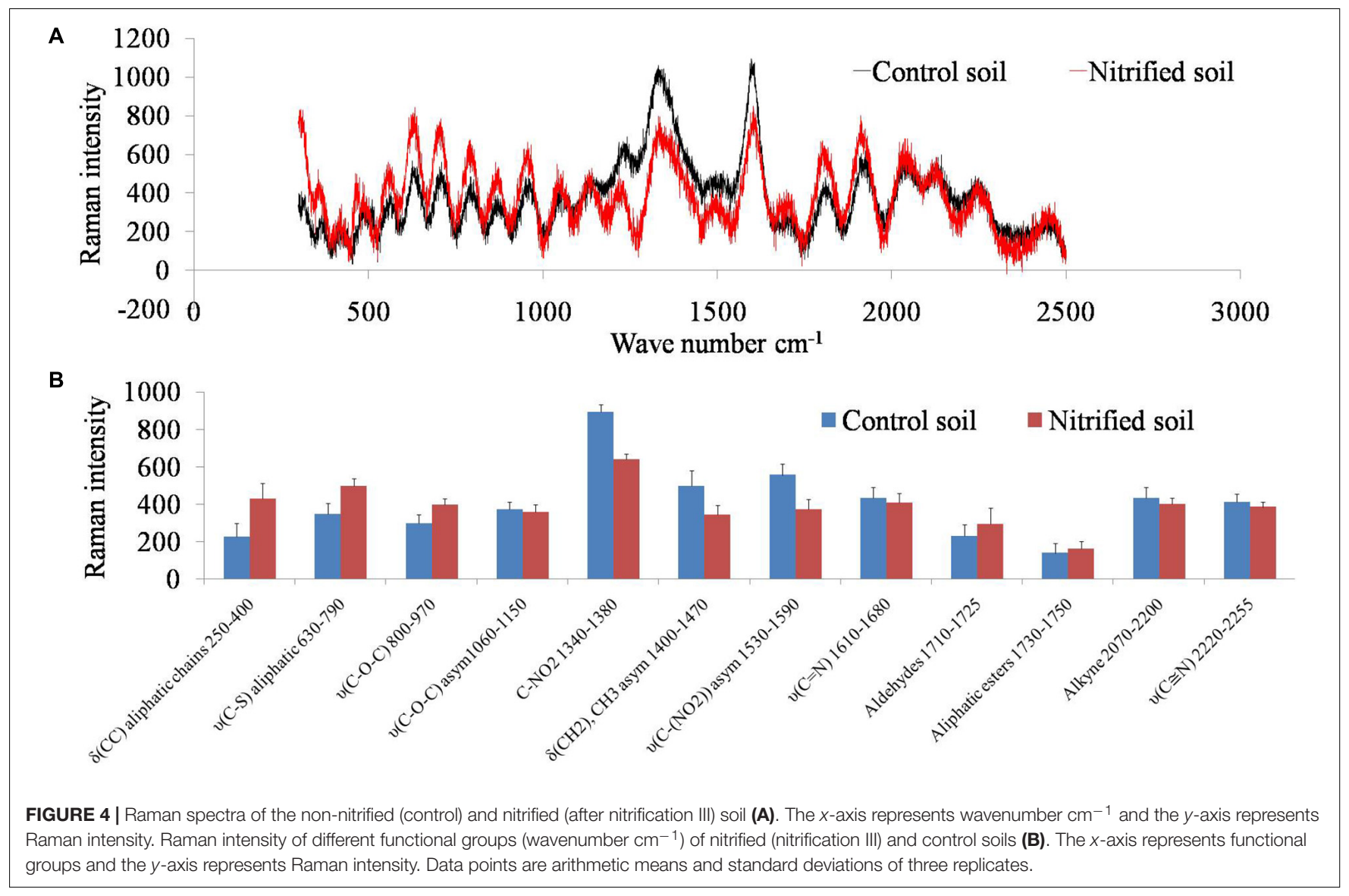

TABLE 4 | Production rates of $\mathrm{N}_{2} \mathrm{O}, \mathrm{CO}_{2}$, potential rates of nitrification and denitrification in soil in response to repeated ammonium additions.

\begin{tabular}{|c|c|c|c|c|}
\hline Nitrification & $\begin{array}{l}\mathrm{N}_{2} \mathrm{O} \text { production }(\mu \mathrm{g} \\
\left.\text { produced } \mathrm{g}^{-1} \text { soil } \mathrm{d}^{-1}\right)\end{array}$ & $\begin{array}{c}\mathrm{CO}_{2} \text { production }(\mu \mathrm{g} \\
\left.\text { produced } \mathrm{g}^{-1} \text { soil } \mathrm{d}^{-1}\right)\end{array}$ & $\begin{array}{l}\text { Potential nitrification rate }(\mathrm{mM} \\
\left.\mathrm{NO}_{3}{ }^{1-} \text { produced } \mathrm{g}^{-1} \text { soil } \mathrm{d}^{-1}\right)\end{array}$ & $\begin{array}{l}\text { Potential denitrification rate ( } \mathrm{mM} \\
\left.\mathrm{NO}_{3}{ }^{1-} \text { reduced } \mathrm{g}^{-1} \text { soil } \mathrm{d}^{-1}\right)\end{array}$ \\
\hline Control & $4.06 \pm 0.06$ & $465 \pm 50.16$ & $0.42 \pm 0.01$ & $1.37 \pm 0.05$ \\
\hline Nitrification I & $11.97 \pm 0.84$ & $575 \pm 94.85$ & $0.47 \pm 0.02$ & $1.38 \pm 0.06$ \\
\hline Nitrification II & $15.87 \pm 1.80$ & $605 \pm 36.02$ & $0.57 \pm 0.01$ & $1.38 \pm 0.01$ \\
\hline Nitrification III & $19.39 \pm 2.61$ & $649 \pm 39.02$ & $0.84 \pm 0.06$ & $1.38 \pm 0.04$ \\
\hline
\end{tabular}

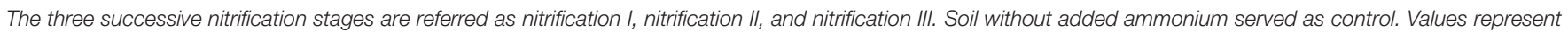
arithmetic means and standard deviations of three replicates.

inhibition of redox metabolism by nitrification may have been due to the presence and/or absence of these functional groups. Under anaerobic conditions, denitrifiers oxidize aliphatic bonds $(\mathrm{C}-\mathrm{C}$ and $\mathrm{C}-\mathrm{O}-\mathrm{C})$ to $\mathrm{CO}_{2}$ through $\mathrm{NO}_{3}{ }^{1-}$ dependent oxidation (Zedelius et al., 2011). Theoretically, the occurrence of aliphatics would stimulate the redox metabolism by acting as substrates for the anaerobic microorganisms. However, in the current experiment, they were correlated with reduced redox metabolism. Probably, the biogenic nitrate was less reactive (denitrifying) than the inorganic $\mathrm{NO}_{3}{ }^{1-}$ as mentioned above. This could be due to the complex interaction or bonding between $\mathrm{NO}_{3}{ }^{1-}$ and the extracellular aliphatics. In control (non-nitrified soil), the $\mathrm{C}-\mathrm{NO}_{2}$ functional groups were high. Spectral data indicated occurrence of biogenic nitrate in soil that has undergone nitrification. Biogenic nitrate is a complex form of nitrate containing organic molecules. The organic molecules can be short- or long-chain aliphatics. The complex structure and bonding between aliphatics and $\mathrm{NO}_{2}{ }^{1-} / \mathrm{NO}_{3}{ }^{1-}$ makes it less reactive to undergo denitrification (Figure 6). It has been found that organic compounds may inhibit denitrification (Gilbert et al., 1997). Probably, the biogenic $\mathrm{NO}_{3}{ }^{1-}$ was denitrified after separation of $\mathrm{NO}_{3}{ }^{1-}$ and aliphatics, which might have been carried out by anaerobic microorganisms (Rabus et al., 2016). The processes of decomposition of the biogenic nitrate by microorganisms probably delayed the availability of $\mathrm{NO}_{3}{ }^{1-}$ for denitrification. Thus, due to the delayed denitrification, there was delay in the reduction of subsequent electron acceptors comprising $\mathrm{Fe}^{3+}, \mathrm{SO}_{4}{ }^{2-}$, and $\mathrm{CH}_{3} \mathrm{COO}^{1-}$ ( $\mathrm{CH}_{4}$ production). 


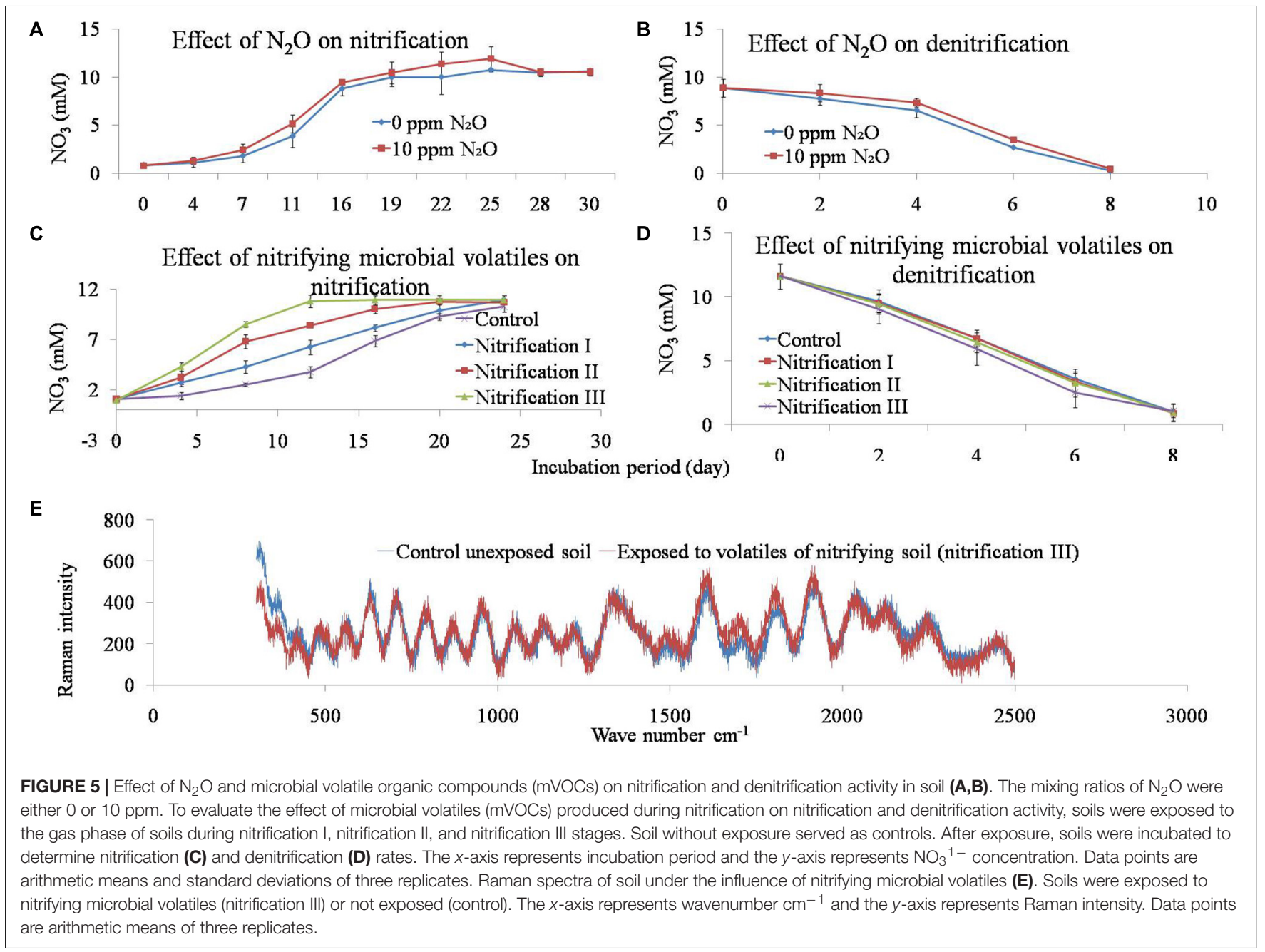

TABLE 5 | Effect of microbial volatiles (mVOCs) produced during nitrification on the abundance of different microbial groups.

\begin{tabular}{|c|c|c|c|c|}
\hline $\begin{array}{l}\text { Nitrifying microbial } \\
\text { volatiles }\end{array}$ & Nitrification & $\begin{array}{c}\text { Eubacteria ( } \times 10^{6} 16 \mathrm{~S} \text { rRNA } \\
\text { gene copies } \mathrm{g}^{-1} \text { soil) }\end{array}$ & $\begin{array}{l}\text { Nitrifying bacteria ( } \times 10^{4} \text { bacterial } \\
\text { amoA gene copies } \mathrm{g}^{-1} \text { soil) }\end{array}$ & $\begin{array}{c}\text { Nitrifying archaea }\left(\times 10^{4} \text { archaeal }\right. \\
\text { amoA gene copies } \mathrm{g}^{-1} \text { soil) }\end{array}$ \\
\hline \multirow[t]{2}{*}{ Un-exposed } & Before nitrification & $5.67 \pm 0.57$ & $4.33 \pm 0.57$ & $6.49 \pm 0.65$ \\
\hline & After nitrification & $43.67 \pm 4.50$ & $103.33 \pm 6.11$ & $93.00 \pm 8.54$ \\
\hline \multirow{2}{*}{$\begin{array}{l}\text { Exposed to nitrifying } \\
\text { volatiles (mVOCs) }\end{array}$} & Before nitrification & $6.00 \pm 1.00$ & $4.67 \pm 1.11$ & $6.67 \pm 1.15$ \\
\hline & After nitrification & $64.67 \pm 3.51$ & $195.67 \pm 12.85$ & $139.33 \pm 16.16$ \\
\hline
\end{tabular}

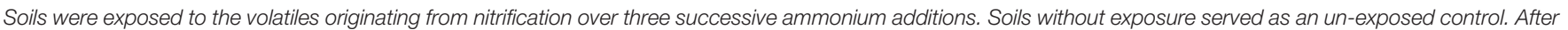

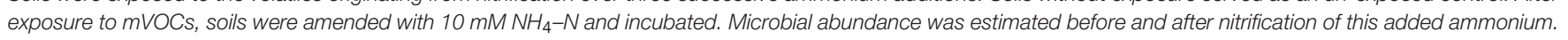
Values represent arithmetic means and standard deviations of three replicates.

It was observed that unlike other microbial activities, nitrification progressed steadily in spite of a constant increase in $\mathrm{NO}_{3}{ }^{1-}$ concentration. Therefore, the formation of biogenic $\mathrm{NO}_{3}{ }^{1-}$ may be a mechanism used by nitrifiers to block the feedback inhibition of $\mathrm{NO}_{3}{ }^{1-}$ to nitrification. Production of $\mathrm{CO}_{2}$ did not significantly vary with nitrification potential. However, $\mathrm{N}_{2} \mathrm{O}$ production varied significantly among the treatments. Nitrous oxide was generally produced from nitrification, because active nitrification (continuous increase in the $\mathrm{NO}_{3}{ }^{1-}$ concentration) was observed over the incubation period. $\mathrm{N}_{2} \mathrm{O}$ production through denitrification cannot be ruled out, because some denitrification might have occurred in the soil microaggregates. However, $\mathrm{NO}_{3}{ }^{1-}$ production from $\mathrm{NH}_{4}$ was consistent and there was no decline in the $\mathrm{NO}_{3}{ }^{1-}$ level. Therefore, the denitrification mediated $\mathrm{N}_{2} \mathrm{O}$ production could be marginal. A followup experiment was carried out to determine the effect of $\mathrm{N}_{2} \mathrm{O}$ on nitrification and denitrification. It was observed that there was no significant effect of $\mathrm{N}_{2} \mathrm{O}$ on nitrification and denitrification. 
A

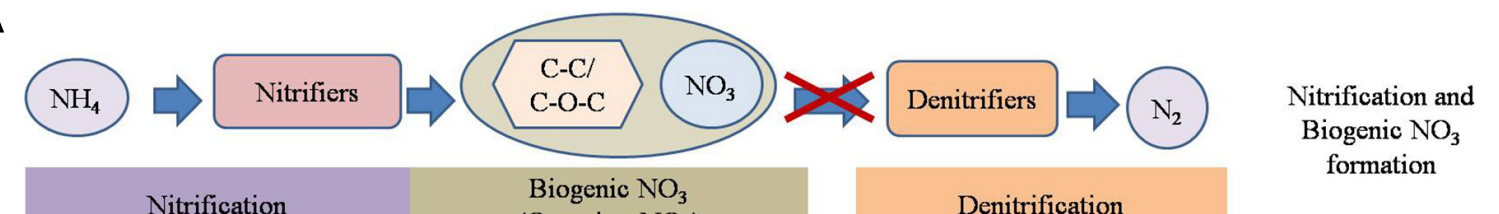

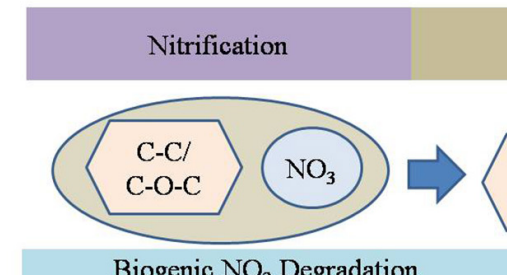

Biogenic $\mathrm{NO}_{3}$ Degradation (Organics $+\mathrm{NO}_{3}$ )

Denitrification formation

Biogenic $\mathrm{NO}_{3}$ degradation and Denitrification

B

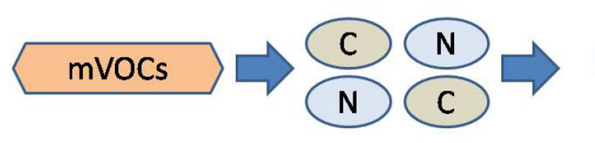

mVOCs degradation

mVOCs

mVOCs bound nitrifiers
Nitrifiers ers

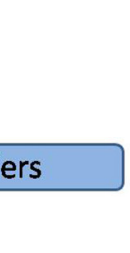

Activated nitrifiers

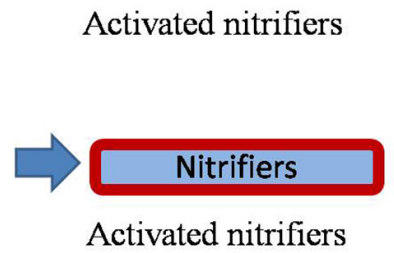

Activated nitrifiers

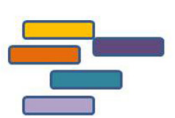

FIGURE 6 | Conceptual model of nitrification and its interaction with the redox metabolism. (A) The proposed mechanism of biogenic nitrate formation and of its interaction with denitrification. Biogenic nitrates are produced by the binding of $\mathrm{NO}_{3}{ }^{1-}$ with extracellular organic compounds, possibly aliphatics. The biogenic nitrates are degraded before onset of redox metabolism under anaerobic conditions. (B) The proposed role of microbial volatile organic compounds ( $\mathrm{mVOCs}$ ) emitted by nitrifiers on soil nitrification. It is hypothesized that mVOCs acts as nutrients for proliferation of certain microbial groups and/or bind to cell membrane proteins to activate nitrifiers.

Apart from $\mathrm{CO}_{2}$ and $\mathrm{N}_{2} \mathrm{O}$, other gaseous products emitted by soil microorganisms include mVOCs. Soil microbes produce VOCs including alkenes, alcohols, ketones, terpenes, benenoids, pyrazines, acids, and esters (Lemfack et al., 2013). Microbial volatiles act as signal molecules to other microorganisms, plants, and animals (Insam and Seewald, 2010). The composition of mVOCs originating from nitrification was beyond the scope of this research, which aims only to provide primary information about the influence of mVOCs on nitrification and denitrification. Based on the current study, conceptual models were developed depicting the potential interaction of mVOCs and nitrifiers (Figure 6). This experiment suggested that mVOCs stimulated nitrification, but no effect on denitrification. Probably, the mVOCs acted as signal molecules for the nitrifiers and stimulated their activity (nitrification). Exposure of soil to mVOCs did not increase the abundance of bacteria, nitrifying bacteria, and nitrifying archaea, suggesting that mVOCs stimulated the nitrifiers by increasing cell activity. Many bacteria decompose VOCs in soil (Tyc et al., 2016). The degraded products could have played important role in the activation of microbial population, resulting in high nitrification rates compared to the unexposed control. Soils after exposure to mVOCs were further tested by Raman spectrometer to evaluate if the volatiles altered chemical composition. However, mVOCs did not change the measured soil properties. We propose that the mVOCs stimulate nitrifiers by acting as signal molecules rather than altering the soil properties.

\section{CONCLUSION}

The current experiment addressed four key questions about nitrification. First, how does nitrification progress under repeated $\mathrm{N}$ amendment? Second, how does nitrification influence redox metabolism? Third, how does the nitrate produced from nitrification (biogenic nitrate) differ from inorganic nitrate? Fourth, do the nitrifiers communicate by means of VOCs? Nitrification activity was observed under three repeated $\mathrm{N}$ amendments. Nitrification increased steadily in respect to the $\mathrm{NH}_{4}-\mathrm{N}$ amendment, due to increasing abundance of nitrifying bacteria and nitrifying archaea. After each nitrification stage, soils were incubated to undergo redox metabolism. An initial nitrification phase inhibited redox rates compared to the addition of an equivalent amount of inorganic $\mathrm{NO}_{3}{ }^{1-}\left(\mathrm{KNO}_{3}\right)$. Raman spectra of the nitrified soils revealed an increased concentration of aliphatics. Based on these observations, it was hypothesized that during nitrification, biogenic nitrates are produced by complex interaction (bonding) between $\mathrm{NO}_{3}{ }^{1-}$ and the aliphatics, and that this biogenic nitrate is less reactive toward 
denitrification than is inorganic nitrate. Nitrifiers emitted VOCs which stimulated nitrification. Nitrification was accelerated by both VOCs and biogenic nitrate. The current experiment mostly indicated the formation of biogenic nitrate and mVOCs by nitrifiers which regulate nitrification and redox metabolism. However, there is need of comprehensive studies on the biochemical characteristics of biogenic nitrate and mVOCs to better understand the nitrification. Further studies are also warranted with other soil types as well as under field conditions to verify complex interaction between biogenic nitrate, VOCs, and nitrification.

\section{AUTHOR CONTRIBUTIONS}

SRM conceptualized the experiments, and drafted the manuscript. MN executed experiments and performed most of the wet chemical analysis. RP assisted in setting up experiments. UA contributed in analyzing redox moieties of soil samples. AP facilitated experiments. GD performed qPCR reactions to quantify functional genes. BK analyzed

\section{REFERENCES}

Alfreider, A., Baumer, A., Bogensperger, T., Posch, T., Salcher, M. M., and Summerer, M. (2017). CO2 assimilation strategies in stratified lakes: diversity and distribution patterns of chemolithoautotrophs. Environ. Microbiol. 19, 2754-2768. doi: 10.1111/1462-2920.13786

Arregui, L. M., and Quemada, M. (2008). Strategies to improve nitrogen use efficiency in winter cereal crops under rainfed conditions. Agron. J. 100, $277-$ 284. doi: 10.2134/agronj2007.0187

Baek, K. H., Park, C., Oh, H.-M., Yoon, B.-D., and Kim, H.-S. (2010). Diversity and abundance of ammonia-oxidizing bacteria in activated sludge treating different types of wastewater. J. Microbiol. Biotechnol. 20, 1128-1133. doi: 10.4014/jmb. 0907.07021

Bock, E., and Wagner, M. (2013). "Oxidation of inorganic nitrogen compounds as an energy source," in The Prokaryotes, eds E. Osenberg, E. F. DeLong, S. Lory, E. Stackebrandt, and F. Thompson (Berlin: Springer), 83-118.

Castro-Barros, C. M., Jia, M., van Loosdrecht, M. C., Volcke, E. I., and Winkler, M. K. (2017). Evaluating the potential for dissimilatory nitrate reduction by anammox bacteria for municipal wastewater treatment. Bioresour. Technol. 233, 363-372. doi: 10.1016/j.biortech.2017.02.063

Colthup, N. (2012). Introduction to Infrared and Raman Spectroscopy. Amsterdam: Elsevier.

Daims, H., Lebedeva, E. V., Pjevac, P., Han, P., Herbold, C., Albertsen, M., et al. (2015). Complete nitrification by Nitrospira bacteria. Nature 528:504. doi: 10 . $1038 /$ nature 16461

Dolinšek, J., Lagkouvardos, I., Wanek, W., Wagner, M., and Daims, H. (2013). Interactions of nitrifying bacteria and heterotrophs: identification of a Micavibrio-like putative predator of Nitrospira spp. Appl. Environ. Microbiol. 79, 2027-2037. doi: 10.1128/AEM.03408-12

Fierer, N., Schimel, J. P., Cates, R. G., and Zou, J. (2001). Influence of balsam poplar tannin fractions on carbon and nitrogen dynamics in Alaskan taiga floodplain soils. Soil Biol. Biochem. 33, 1827-1839. doi: 10.1016/S0038-0717(01)00111-0

Flood, M., Frabutt, D., Floyd, D., Powers, A., Ezegwe, U., Devol, A., et al. (2015). Ammonia-oxidizing bacteria and archaea in sediments of the Gulf of Mexico. Environ. Technol. 36, 124-135. doi: 10.1080/09593330.2014.942385

Gilbert, F., Stora, G., Bonin, P., LeDréau, Y., Mille, G., and Bertrand, J.-C. (1997). Hydrocarbon influence on denitrification in bioturbated Mediterranean coastal sediments. Hydrobiologia 345, 67-77. doi: 10.1023/A:1002931432250

Gribaldo, S., Poole, A. M., Daubin, V., Forterre, P., and Brochier-Armanet, C. (2010). The origin of eukaryotes and their relationship with the Archaea: are we at a phylogenomic impasse? Nat. Rev. Microbiol. 8, 743-752. doi: 10.1038/ nrmicro2426 data statistically and contributed in drafting and revising the manuscript.

\section{FUNDING}

This study is part of the ICAR AMAAS and DST funded India Argentina bilateral project.

\section{ACKNOWLEDGMENTS}

We thank Dr. Peter Dunfield for his input improving the manuscript.

\section{SUPPLEMENTARY MATERIAL}

The Supplementary Material for this article can be found online at: https://www.frontiersin.org/articles/10.3389/fmicb. 2019.00772/full\#supplementary-material

Guizani, C., Haddad, K., Limousy, L., and Jeguirim, M. (2017). New insights on the structural evolution of biomass char upon pyrolysis as revealed by the Raman spectroscopy and elemental analysis. Carbon 119, 519-521. doi: 10. 1016/j.carbon.2017.04.078

Han, S., Luo, X., Liao, H., Nie, H., Chen, W., and Huang, Q. (2017). Nitrospira are more sensitive than Nitrobacter to land management in acid, fertilized soils of a rapeseed-rice rotation field trial. Sci. Total Environ. 599, 135-144. doi: 10.1016/j.scitotenv.2017.04.086

Ihaka, R., and Gentleman, R. (1996). R: a language for data analysis and graphics. J. Comput. Graph. Stat. 5, 299-314.

Insam, H., and Seewald, M. S. (2010). Volatile organic compounds (VOCs) in soils. Biol. Fertil. Soils 46, 199-213. doi: 10.1007/s00374-0100442-3

Ionescu, D., Heim, C., Polerecky, L., Ramette, A., Haeusler, S., Bizic-Ionescu, M., et al. (2015). Diversity of iron oxidizing and reducing bacteria in flow reactors in the Äspö hard rock laboratory. Geomicrobiol. J. 32, 207-220. doi: 10.1080/ 01490451.2014 .884196

Isobe, K., Koba, K., Suwa, Y., Ikutani, J., Fang, Y., Yoh, M., et al. (2012). High abundance of ammonia-oxidizing archaea in acidified subtropical forest soils in southern China after long-term N deposition. FEMS Microbiol. Ecol. 80, 193-203. doi: 10.1111/j.1574-6941.2011.01294.x

Jackson, M. L. (1958). Soil Chemical Analysis. Englewood, NJ: Prentice- Hall, Inc.

Leininger, S., Urich, T., Schloter, M., Schwark, L., Qi, J., Nicol, G. W., et al. (2006). Archaea predominate among ammonia-oxidizing prokaryotes in soils. Nature 442, 806-809. doi: 10.1038/nature04983

Lemfack, M. C., Nickel, J., Dunkel, M., Preissner, R., and Piechulla, B. (2013). mVOC: a database of microbial volatiles. Nucleic Acids Res. 42, D744-D748. doi: $10.1093 /$ nar/gkt1250

Li, J., Wei, J., Ngo, H. H., Guo, W., Liu, H., Du, B., et al. (2018). Characterization of soluble microbial products in a partial nitrification sequencing batch biofilm reactor treating high ammonia nitrogen wastewater. Bioresour. Technol. 249, 241-246. doi: 10.1016/j.biortech.2017.10.013

Li, Y., Chapman, S. J., Nicol, G. W., and Yao, H. (2018). Nitrification and nitrifiers in acidic soils. Soil Biol. Biochem. 116, 290-301. doi: 10.1016/j.soilbio.2017.10. 023

Liimatainen, M., Voigt, C., Martikainen, P. J., Hytönen, J., Regina, K., Óskarsson, H., et al. (2018). Factors controlling nitrous oxide emissions from managed northern peat soils with low carbon to nitrogen ratio. Soil Biol. Biochem. 122, 186-195. doi: 10.1016/j.soilbio.2018.04.006

Lliros, M., Ingeoglu, O., Garcia-Armisen, T., Auguet, J. C., Morana, C., Darchambeau, F., et al. (2014). "Ammonia oxidising Archaea in the OMZ of a freshwater African Lake," in Proceedings of the 46th International Liège 
Colloquium, Low Oxygen Environments in Marine, Estuarine and Fresh Waters, (Liège).

Mutlu, M. B., and Guven, K. (2011). Detection of prokaryotic microbial communities of Çamaltı Saltern, Turkey, by fluorescein in situ hybridization and real-time PCR. Turk. J. Biol. 35, 687-695.

Nelson, M. B., Martiny, A. C., and Martiny, J. B. (2016). Global biogeography of microbial nitrogen-cycling traits in soil. Proc. Natl. Acad. Sci. U.S.A. 113, 8033-8040. doi: 10.1073/pnas.1601070113

Okano, Y., Hristova, K. R., Leutenegger, C. M., Jackson, L. E., Denison, R. F., Gebreyesus, B., et al. (2004). Application of real-time PCR to study effects of ammonium on population size of ammonia-oxidizing bacteria in soil. Appl. Environ. Microbiol. 70, 1008-1016. doi: 10.1128/AEM.70.2.1008-1016.2004

Ontiveros-Valencia, A., Ilhan, Z. E., Kang, D.-W., Rittmann, B., and KrajmalnikBrown, R. (2013). Phylogenetic analysis of nitrate-and sulfate-reducing bacteria in a hydrogen-fed biofilm. FEMS Microbiol. Ecol. 85, 158-167. doi: 10.1111/ 1574-6941.12107

Pan, K.-L., Gao, J.-F., Li, H.-Y., Fan, X.-Y., Li, D.-C., and Jiang, H. (2018). Ammonia-oxidizing bacteria dominate ammonia oxidation in a full-scale wastewater treatment plant revealed by DNA-based stable isotope probing. Bioresour. Technol. 256, 152-159. doi: 10.1016/j.biortech.2018.02.012

Rabus, R., Boll, M., Heider, J., Meckenstock, R. U., Buckel, W., Einsle, O., et al. (2016). Anaerobic microbial degradation of hydrocarbons: from enzymatic reactions to the environment. J. Mol. Microbiol. Biotechnol. 26, 5-28. doi: 10. $1159 / 000443997$

Radax, R., Hoffmann, F., Rapp, H. T., Leininger, S., and Schleper, C. (2012). Ammonia-oxidizing archaea as main drivers of nitrification in cold-water sponges. Environ. Microbiol. 14, 909-923. doi: 10.1111/j.1462-2920.2011. 02661.x

Rissanen, A. J., Karvinen, A., Nykänen, H., Peura, S., Tiirola, M., Mäki, A., et al. (2017). Effects of alternative electron acceptors on the activity and community structure of methane-producing and-consuming microbes in the sediments of two shallow boreal lakes. FEMS Microbiol. Ecol. 93, 1-16. doi: 10.1093/femsec/ fix 078

Rubio-Asensio, J. S., López-Berenguer, C., García-de la Garma, J., Burger, M., and Bloom, A. J. (2014). "Root strategies for nitrate assimilation," in Root Engineering, eds A. Morte and A. Varma (Berlin: Springer), 251-267.

Schmidt, E. L., and Belser, L. W. (1982). Nitrifying bacteria. Methods Soil Anal. Part 2, 1027-1042.

Searle, P. L. (1979). Measurement of adsorbed sulphate in soils-effects of varying soil: extractant ratios and methods of measurement. N. Z. J. Agric. Res. 22, 287-290. doi: 10.1080/00288233.1979.10430749
Socrates, G. (2004). Infrared and Raman Characteristic Group Frequencies: Tables and Charts. Hoboken, NJ: John Wiley \& Sons.

Stookey, L. L. (1970). Ferrozine - a new spectrophotometric reagent for iron. Anal. Chem. 42, 779-781. doi: 10.1021/ac60289a016

Tourna, M., Stieglmeier, M., Spang, A., Könneke, M., Schintlmeister, A., Urich, T., et al. (2011). Nitrososphaera viennensis, an ammonia oxidizing archaeon from soil. Proc. Natl. Acad. Sci. U.S.A. 108, 8420-8425. doi: 10.1073/pnas. 101348 8108

Tyc, O., Song, C., Dickschat, J. S., Vos, M., and Garbeva, P. (2016). The ecological role of volatile and soluble secondary metabolites produced by soil bacteria. Trends Microbiol. 25, 280-292. doi: 10.1016/j.tim.2016.12.002

van Kessel, M. A., Speth, D. R., Albertsen, M., Nielsen, P. H., den Camp, H. J. O., Kartal, B., et al. (2015). Complete nitrification by a single microorganism. Nature 528:555. doi: 10.1038/nature16459

Weber, E. B., Lehtovirta-Morley, L. E., Prosser, J. I., and Gubry-Rangin, C. (2015). Ammonia oxidation is not required for growth of Group $1.1 \mathrm{c}$ soil Thaumarchaeota. FEMS Microbiol. Ecol. 91:fiv001. doi: 10.1093/femsec/ fiv001

Wuchter, C., Abbas, B., Coolen, M. J., Herfort, L., van Bleijswijk, J., Timmers, P., et al. (2006). Archaeal nitrification in the ocean. Proc. Natl. Acad. Sci. U.S.A. 103, 12317-12322. doi: 10.1073/pnas.0600756103

Zedelius, J., Rabus, R., Grundmann, O., Werner, I., Brodkorb, D., Schreiber, F., et al. (2011). Alkane degradation under anoxic conditions by a nitrate-reducing bacterium with possible involvement of the electron acceptor in substrate activation. Environ. Microbiol. Rep. 3, 125-135. doi: 10.1111/j.1758-2229.2010. 00198.x

Zhao, J., Wang, B., and Jia, Z. (2015). Phylogenetically distinct phylotypes modulate nitrification in a paddy soil. Appl. Environ. Microbiol. 81, 3218-3227. doi: 10. 1128/AEM.00426-15

Conflict of Interest Statement: The authors declare that the research was conducted in the absence of any commercial or financial relationships that could be construed as a potential conflict of interest.

Copyright (C) 2019 Mohanty, Nagarjuna, Parmar, Ahirwar, Patra, Dubey and Kollah. This is an open-access article distributed under the terms of the Creative Commons Attribution License (CC BY). The use, distribution or reproduction in other forums is permitted, provided the original author(s) and the copyright owner(s) are credited and that the original publication in this journal is cited, in accordance with accepted academic practice. No use, distribution or reproduction is permitted which does not comply with these terms. 